\title{
Public Square Design with Snow and Wind Simulations Using Wind Tunnel
}

\author{
Tsuyoshi Setoguchi \\ Faculty of Engineering, Hokkaido University \\ Japan
}

\section{Introduction}

\subsection{The purpose of the research}

A Snow is one of the most influence points to urban design for snow and cold region. In cities that are located in heavy snowfall and cold regions like Hokkaido, it is important to clarify how to apply urban design principles to protect areas with a harsh winter climate. Specifically, significant issues should be addressed concerning the environmental impact of snow and wind on public spaces of the urban renewal projects.

In addition, desirable urban designs providing better environments in public spaces that protect against snow and wind in winter should be developed. The need has been felt for original approaches to urban design in such cities. An urban design which reduces snow problems (e.g. snowdrifts or blowing snow) is one method promoting "symbioses" between humans, snow and cold climate in those cities.

In this paper, the author targeted the redevelopment project of the new Wakkanai Station Square, in Hokkaido Japan. The actual project was started in 2003 and produced by City of Wakkanai, as part of the Urban Revitalization Program in Japanese Local Cities. This author and Wakkanai City started the co-research project for a desirable design for Wakkanai Station Square with consideration given to the local climate in winter.

In Wakkanai City northernmost city of Japan, the Wakkanai Station and Station Square redevelopment project have been launched. For the Square desirable space design preventing from snow and strong wind is required on the public square. In this paper, the author targeted the redevelopment project of the new Wakkanai Station Square, in Hokkaido Japan.

Author focused on a Covered-Walk (CW) design for the square for protecting passengers and pedestrians against snow and wind ${ }^{{ }_{1}}$. Two types of $\mathrm{CW}$ design were tested in a snow simulation, a leeward side CW type and a windward side CW type. The snow simulation tests were carried out using the wind tunnel in the Hokkaido Northern Regional Building Research Institute. The results of this simulation will be reflected in the square planning and design of this project.

\subsection{Previous studies}

Many environmental assessments for urban design have been conducted in Japan incorporating wind simulation tests, but there has been little published research with both 
snow and wind factors taken into account other than that by Yoshizaka et al. (1942)1) and this author. They had indicated desirable low-rise building locations and directions against snow and wind in mountainous rural area of the Tohoku region in Japan, where it snows heavily in winter.

Bosselmann (19842), 19893), 19984)) produced useful studies of downtown San Francisco in the U.S. and downtown Toronto in Canada, and showed that new developments with highrise buildings cause environmental problems due to alterations in wind and sunlight patterns in the surrounding areas. He compared the environmental impact of high-rise and medium-rise buildings in wind simulation tests using a wind tunnel. These results showed that new developments with medium-rise buildings had a reduced negative environmental impact on their surrounding areas, and proved that medium-rise buildings were one of the more desirable urban designs for the downtown area. In San Francisco, environmental impact evaluations of new developments are required by ordinance and the findings must be considered in a public hearing by the city planning committee. Wind simulation tests studying environmental impact can provide useful data and can influence the outcome of public hearings.

Tomabechi (2002)5) carried out a different kind of simulation, that of snow impact, using a wind tunnel. His approach was to show desirable building locations regarding snow and wind in Hokkaido, Japan. The results of the simulation tests were useful, but the effectiveness of those results was only applicable to building design, not to city planning or urban design. The useful snow simulation approaches using wind tunnel for urban design, it is required to expand the targeted area to the district level.

To this author's knowledge, there has been little research on the environmental influence of snow and wind for urban design using snow simulation tests utilizing a wind tunnel (Table 1).

\begin{tabular}{|c|c|c|}
\hline Simulation & Building Design & Urban Design \\
\hline $\begin{array}{c}\text { Using } \\
\text { Only Wind }\end{array}$ & (Many researches) & Bosselmann $(1984,1989,1998)$ \\
\hline $\begin{array}{c}\text { Using } \\
\text { Wind \& Snow }\end{array}$ & Tomabechi (2002) & Setoguchi (20036), 20047)) \\
\hline
\end{tabular}

Table 1. References of Researches for Environmental Impacts with Snow or Wind Using Wind Tunnel

\section{Wind tunnel for the snow simulation tests}

\subsection{Wakkanai city: The most serious winter climate in Japan \\ 2.1.1 Snowfall regions in Japan}

In Japan, there are many cities and villages that are located in areas that experience heavy snowfall ${ }^{* 2}$. Around $51 \%$ of the land is in areas that experience heavy snowfall, and $16 \%$ of the population lives in such areas. Heavy snowfall is one of the most important issues for city planning, but enough consideration of the problem is not given by urban planners. Wakkanai City is the northernmost city in Japan, and is definitely located in an area of heavy snowfall (Fig. 1). 


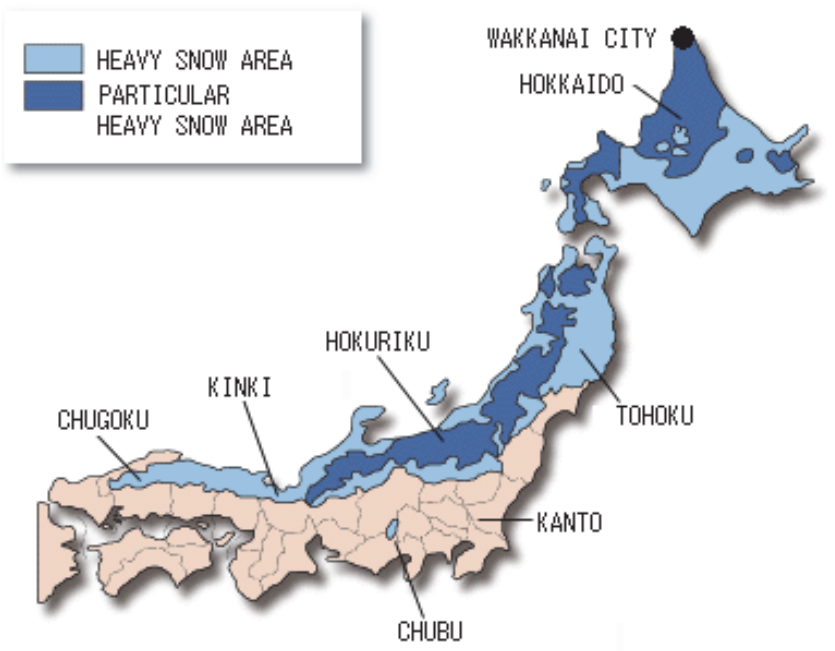

Fig. 1. Heavy snow areas in Japan (Source: Ministry of Land Infrastructure and Transport)

\subsubsection{Local winter climate of Wakkanai city}

Hokkaido is located in the northern part of Japan, which is a cold and heavy snowfall region. There are many cities and towns which experience snowstorms in winter in Hokkaido. Cities in the cape area, including Wakkanai City especially, experience strong snowstorms frequently. Table 2 shows the frequency of snowstorms for cities and towns in Hokkaido.

Wakkanai City is hit by snowstorms frequently, and is second only to Rumoi City in terms of such frequent cities. On a typical day in winter its chance of experiencing a snowstorm is 35.7 times the national average, and so its citizens must cope with snowstorms almost every day. Although heavy snowfall and snowstorms are one of the most important issues concerning urban design, not enough consideration is given to this problem by planners. As Japan's northernmost city Wakkanai City is definitely located in a strong snowstorm area.

\begin{tabular}{cccc}
\hline Order & Name of Municipality & $\begin{array}{c}\text { City, Town or } \\
\text { Village }\end{array}$ & $\begin{array}{c}\text { Frequency of } \\
\text { Snowstorms (per day) }\end{array}$ \\
\hline 1 & Rebun & Town & 51.7 \\
2 & Suttsu & Town & 44.2 \\
3 & Matsumae & Town & 42.5 \\
4 & Esashi & Town & 42.5 \\
5 & Rumoi & City & 42.5 \\
6 & Haboro & Town & 37.9 \\
7 & Iwanai & Town & 36.9 \\
8 & Wakkanai & City & 35.7 \\
9 & Rishiri & Town & 35.5 \\
10 & Enbetsu & Town & 34.2 \\
\hline
\end{tabular}

Table 2. Frequency of Snowstorms in Cities and Towns in Hokkaido (snowstorms hitting to the downtown area) 


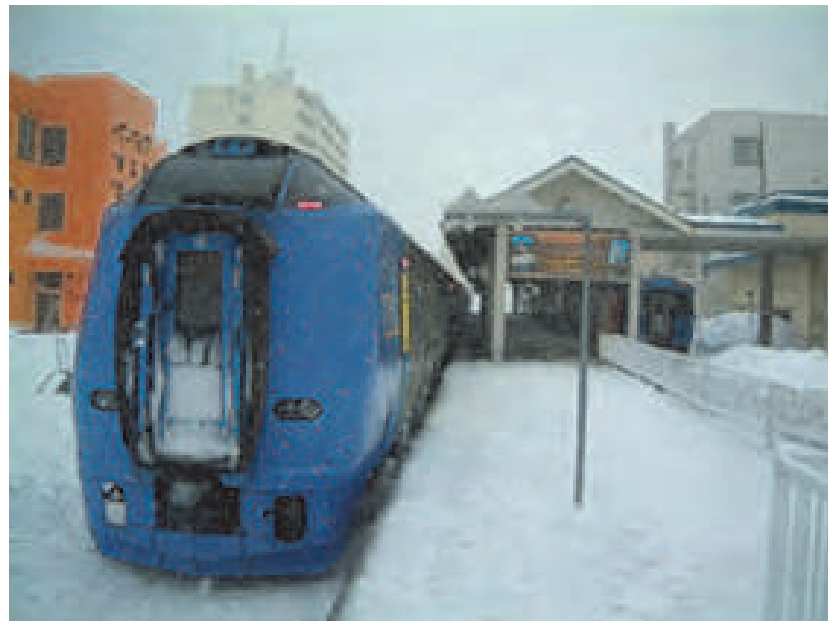

Photo 1. Wakkanai station covered with snow in winter

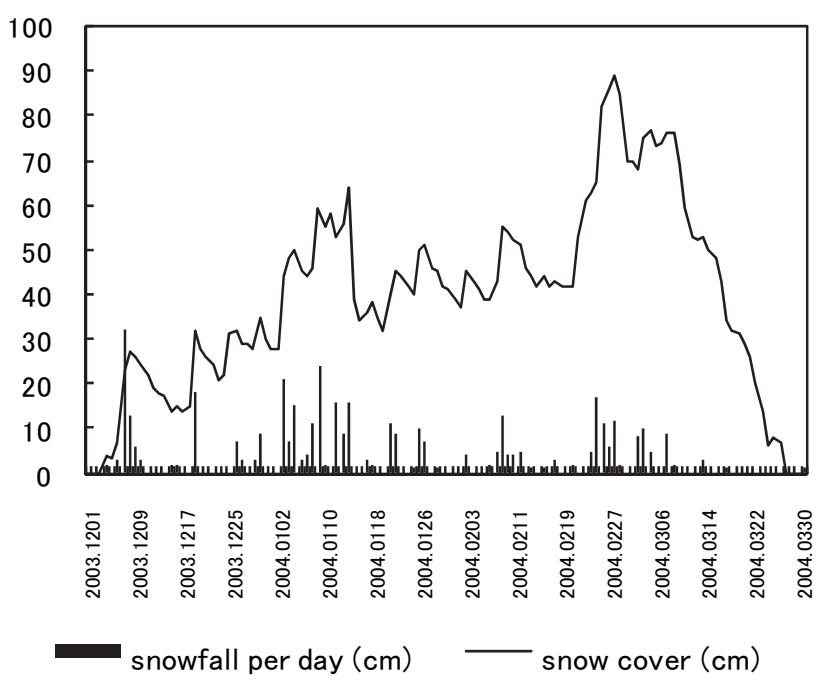

Fig. 2. Snow accumulating data of downtown Wakkanai

Figure 2 shows snow data during the winter season in downtown Wakkanai as observed by the Meteorological Agency. In that year, snow cover began from the beginning of December and it continued until the end of March of the following year. Thus, the land was covered with snow for around four months in downtown Wakkanai. The depth of the snow increased step by step from December and reached a peak of $89 \mathrm{~cm}$ on February $28 \mathrm{th}$. It means pedestrians way also covered by snow during four month winter in the downtown Wakkanai. 


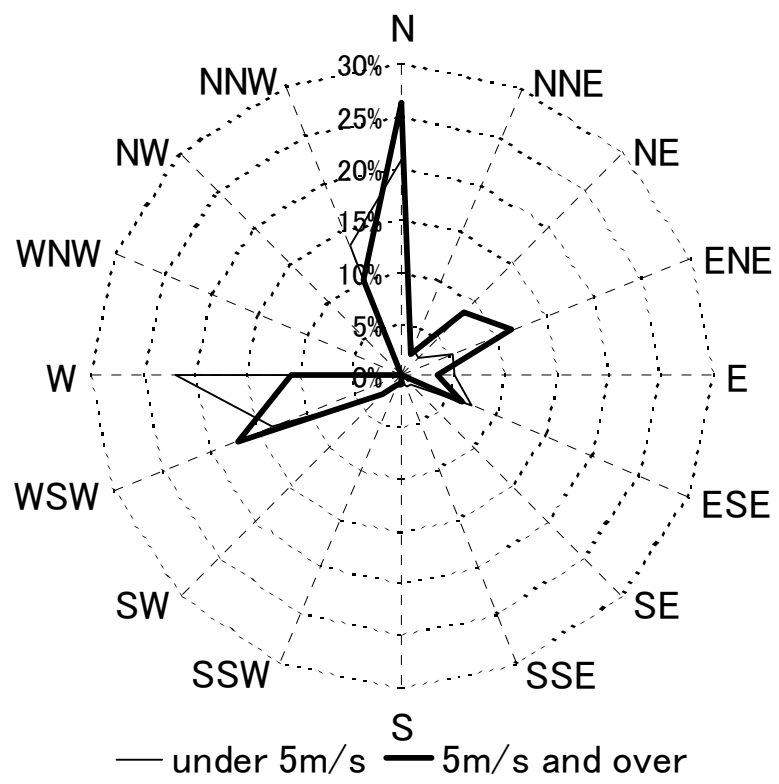

Fig. 3. Wind velocity data of downtown Wakkanai

According to the climate data of the Meteorological Agency during last five years, as for the wind environment, there was strong wind with snow blow from the north $(\mathrm{N})$ and westsouthwest (WSW). Strong wind velocities mostly come from the north in Wakkanai City, so the strongest wind velocity from a northerly direction was adopted for the snow simulation tests (Fig. 3).

\subsection{The wind tunnel for the snow and wind simulations}

The snow simulation tests were carried out using the wind tunnel in the Hokkaido Northern Regional Building Research Institute. The wind tunnel simulation test area is seven meters long, $150 \mathrm{~cm}$ wide and $70 \mathrm{~cm}$ high in the tunnel cross section. (Fig. 4)

The first step in the procedure is to assess the differences between the actual weather data and that of the snow simulation tests with models, and try to modify the weather data for the simulations. Local wind conditions are quantified by testing scale models of the district in a boundary layer of the wind tunnel. The wind tunnel tests give, for each wind direction, a ratio between the wind speeds at the location where the weather data was recorded. The turbulence intensity or gustiness was recognized in the district, but these factors were also considered in changing wind velocities in the wind tunnel simulations in the several trials. Increased turbulence is assumed to be equivalent to an increase in wind speed, using a relationship that has been found for the mechanical effects of wind. The vertical distribution of the wind velocities is shown in Fig. 5.

For the snow simulation tests, the author assumed a snow blow and snowdrift area on the ground as well as a blown white soil and drifted white soil area on the ground model. And the laser device ${ }^{*} 3$ of the wind tunnel measured the heights of the white soil drifts automatically. It was measured at intervals of $2 \mathrm{~mm}$ on the model of the district. 

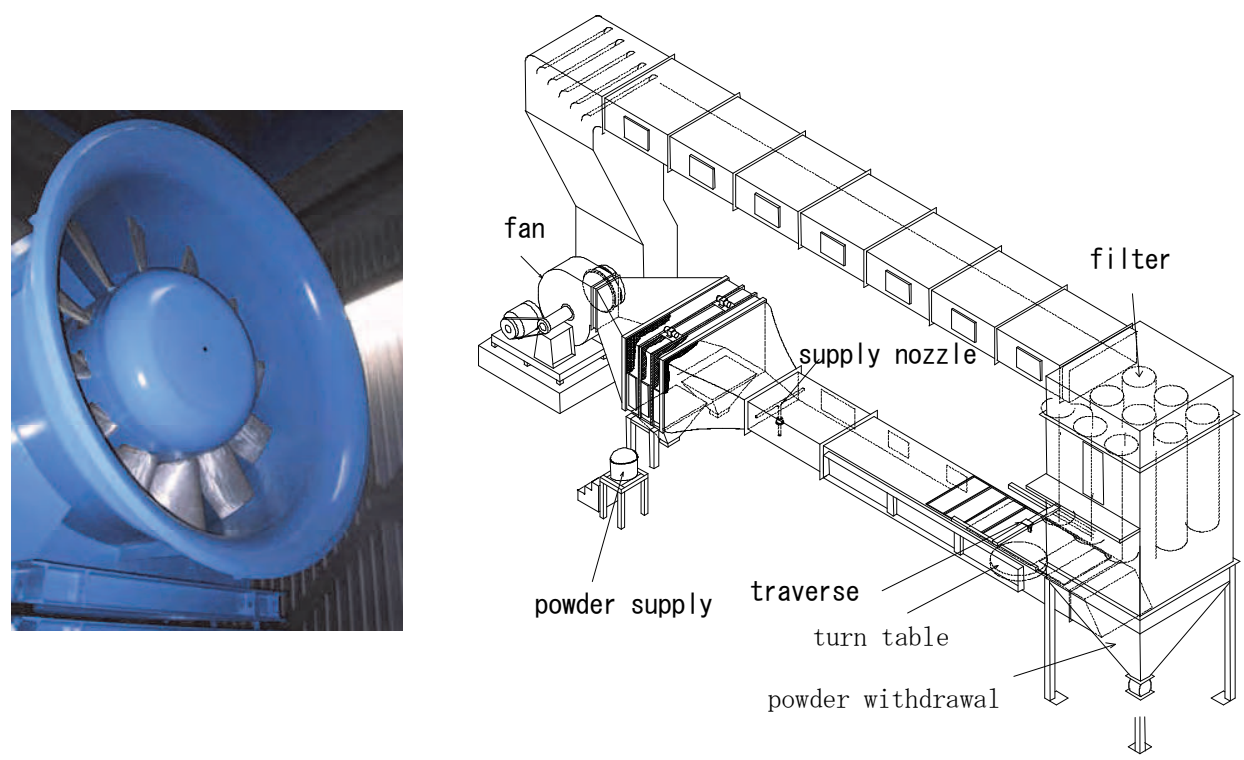

(Hokkaido Northern Regional Building Research Institute)

Fig. 4. Wind Tunnel for the snow simulations

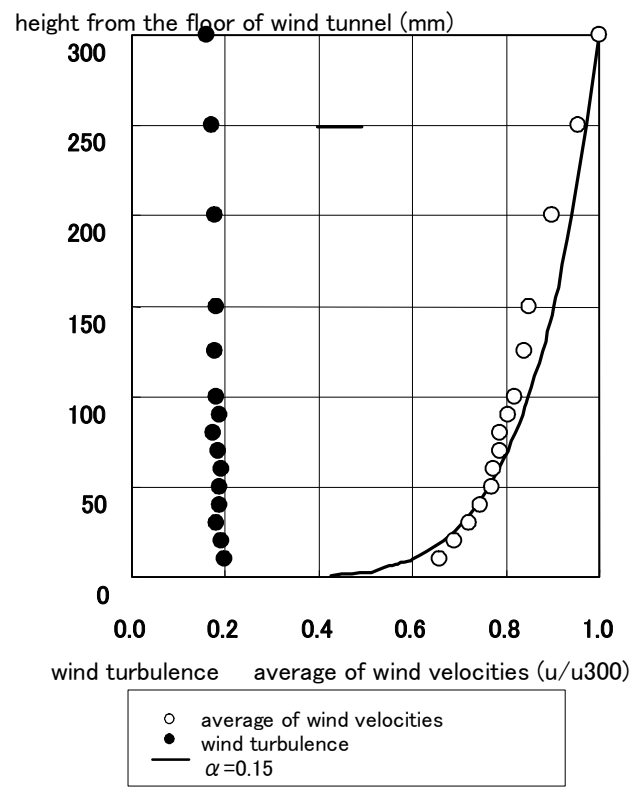

Fig. 5. Vertical distribution of wind velocities in the wind tunnel 
The characteristic point between pure snow in Wakkanai and white soil are similar. Both of drifting angle and shape are similar, the angle of pure snow assumes around from 45 to 50 and the angle of white soil is 46 . This is the reason author adopted white soil for the snow simulations (Fig. 6).

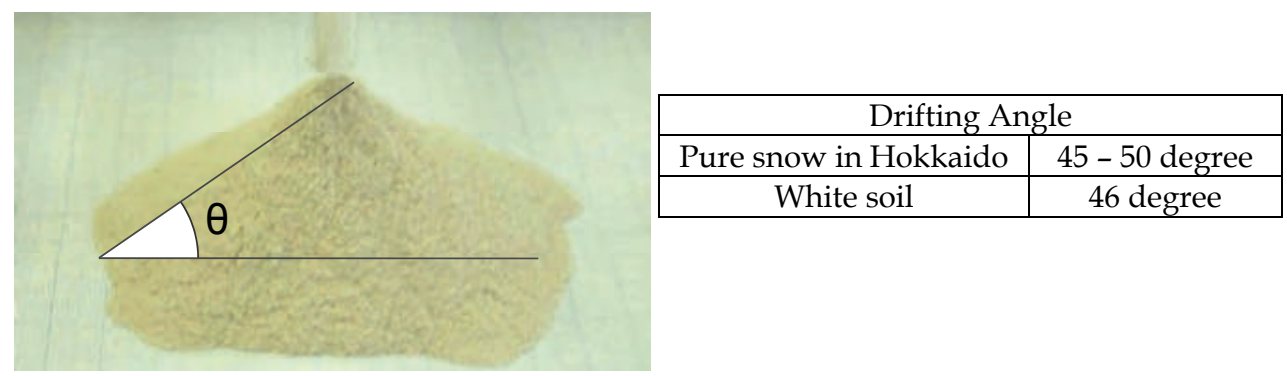

Fig. 6. Comparison the drifting angle between pure snow and white soil

\subsection{Models for snow simulation experiments}

For the snow simulation tests, block models of the target area, the Wakkanai station district, were made of styro-foam in the scale of 1 to 300 . The size of the district is $540 \mathrm{~m}$ (in the north-south direction) by $360 \mathrm{~m}$ (in the east-west direction); therefore the models of the district measured $1800 \mathrm{~mm}$ long by $1200 \mathrm{~mm}$ wide for the snow simulation tests.

The snow models were made of white soil powder ${ }^{*}$. This soil tends to have a drifting pattern similar to that of snow in Hokkaido. It gives a static-free performance in wind tunnels; therefore there was no friction between the powder particles themselves. The ground model boards were painted; therefore there was no friction between the powder and the ground models. The powder for the snow models was supplied from windward side nozzles to the testing area of the tunnel by an air compressor. The CW models were made of acrylic plastic board for no friction with the snow soil powder.
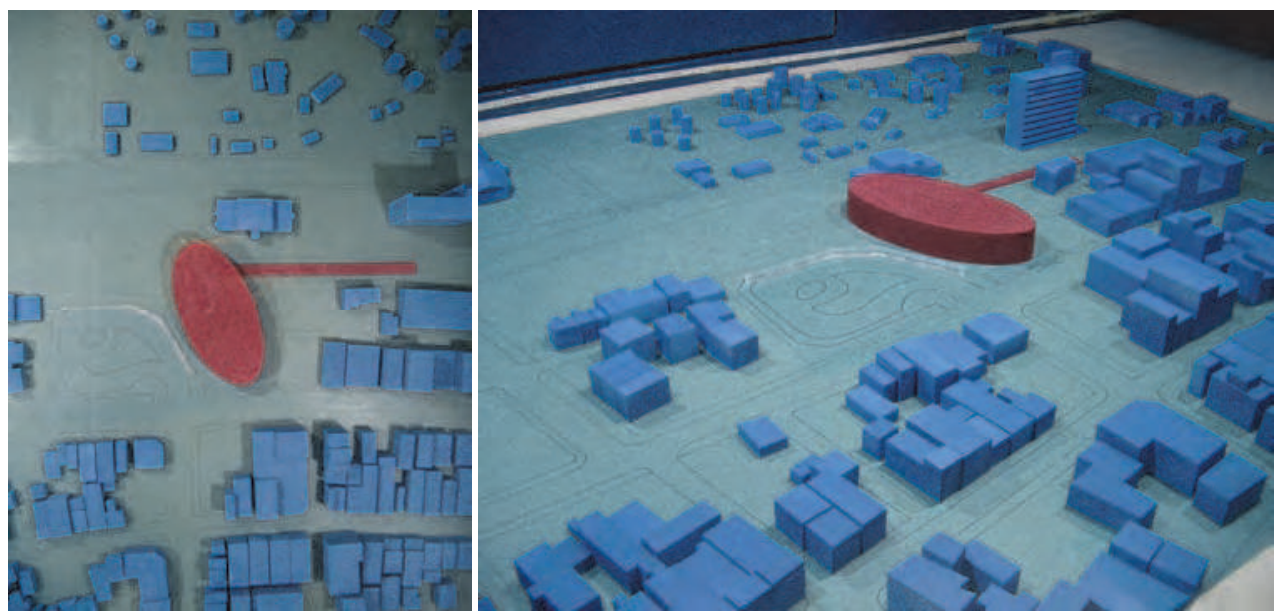

Photo 2. The targeted district models of Downtown Wakkanai 


\section{Assessment items depend on the planning issues}

\subsection{Nine planning approaches for the Wakkanai station project}

On the Wakkanai Station renewal project the nine planning approaches are addressed for the downtown revitalization program as follows.

1. Accessibility: Pedestrians and passenger are able to access easy to the station, bus terminal and the commercial facilities even in winter.

2. Barrier Free: The accessibility is also ensured for elderly and handicapped.

3. Connection: The pedestrians' connection between downtown and water front area is one of the most important network for the downtown revitalization. The urban axis along to the Wakkanai station square will be required less snow damage and snowdrift.

4. Walk-able: Walk-able environment for pedestrian may be ensured on the no snowdrift walkway in winter.

5. Comfortable: Even the outside on the station square comfortable environment should be required for pedestrians and citizens during a year.

6. Community: Making community spaces for citizen will be helpful for their communications. Some of them are inside of the building and some are outside with better comfort environment.

7. Facilities: The Wakkanai Station renewal project promote important facilities rail station and bus terminal. People have much chance to meet together.

8. Mixed Use: The Wakkanai Station renewal project include the development of commercial area and elderly apartments inside the new building. The pedestrian ways have chance that various pedestrian especially elderly people walk on the ways many times.

9. Information: The information for tourist and citizens should be provided accurately. The locations of the information board and signs are also important.

The CW design is also significant to contribute to the Wakkanai Station program for above items Accessibility, Barrier Free, Connection, Walk-able and Comfortable.

\subsection{Planning issues regarding the Wakkanai station square project}

For planning regarding the Wakkanai Station Square ${ }^{* 5}$, the following three issues were addressed. They were pointed out as urban design issues before the snow simulation tests. The Wakkanai station and Station Complex Center were planed integrally and the site was as see Fig. 7. The height of the building was 13.5 meter $(45 \mathrm{~mm}$ heights on the model).

\section{a) Planning for an urban axis with a desirable pedestrian mall for connecting downtown and the port area}

The downtown area and the port area are divided by the JR railway line, and Wakkanai station is located between them. Since a big park is planned for the port area in next decade, an urban axis with a pedestrian mall connecting them is required in the redevelopment plan.

\section{b) Planning for enough area for vehicular traffic in the Station Square}

Enough area is required for vehicular traffic, such as public buses, taxis and private vehicles, in the Wakkanai Station Square even in winter. 


\section{c) Planning for the integration of public transportation}

No barrier should be required for pedestrian to transfer between JR train and public bus. Especially the cross point of the urban axis and the pedestrian route from JR train to Station Square are significant no snow drifting for the desirable pedestrian networking.

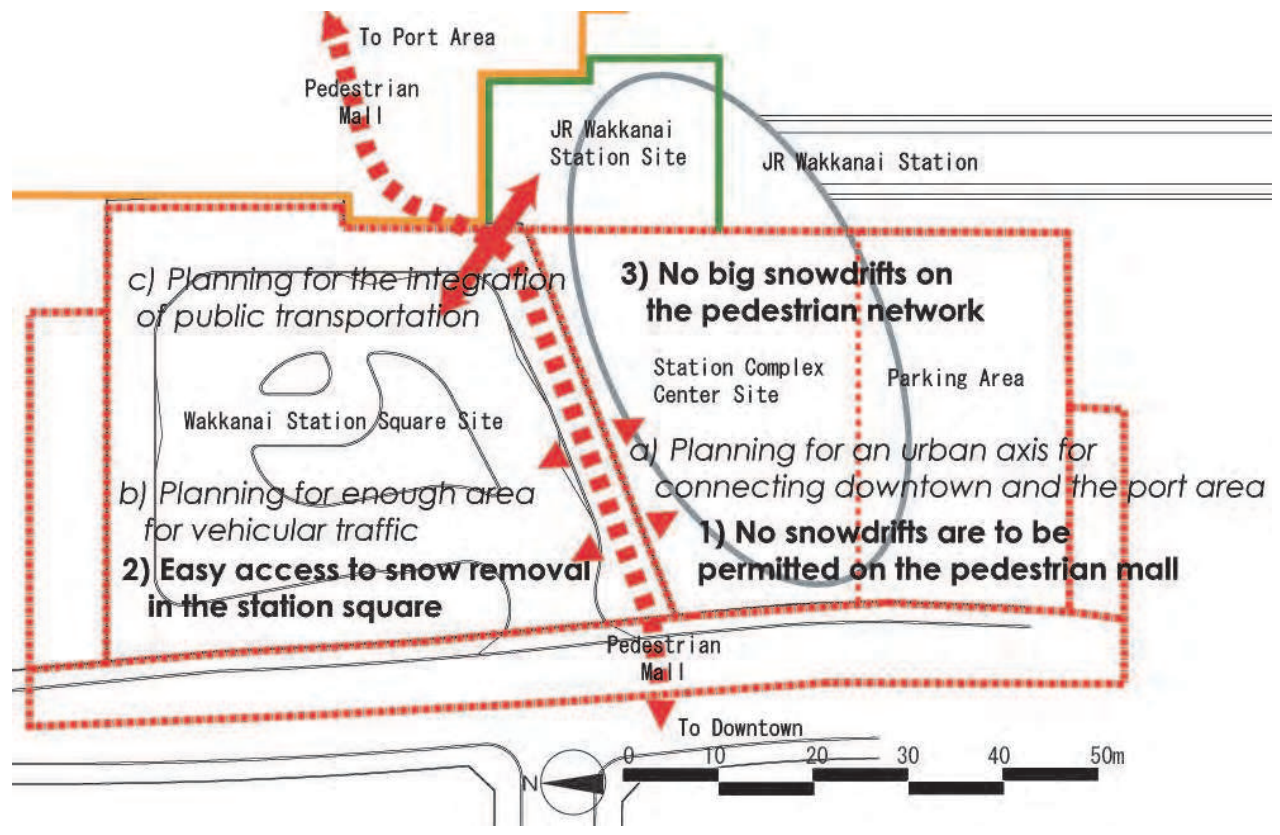

Fig. 7. Planning Issues and Assessment Items on the Wakkanai Station Square Project $<$ a) b) c) are the planning issues, 1) 2) 3) are the assessment items for the snow simulation > $<$ The gray elliptic line means the site of the location of the Station Complex Center>

\subsection{Assessment items regarding snow simulation}

For implementing those planning objectives even in winter, the following three assessment items were addressed regarding each issue. These assessment items were verified in snow simulation tests using the wind tunnel. Basically, these items were based on the concept of reducing the impingement upon pedestrian activity caused by winter snowdrifts in the new redevelopment of Wakkanai Station Square (Fig. 7).

1. No snowdrifts are to be permitted on the pedestrian way connecting downtown and the port area and CW. Various activities will be assumed on the pedestrian way and CW, such as transfer among the various forms of public transportation, flow from downtown to the port area and entrance to the station complex center. Even in winter, snowdrifts should not be an obstacle to the pedestrian network.

2. Easy access to snow removal is to be required in the station square in winter. Enormous piles of snow should not be left in the square because it would interfere with vehicular and pedestrian traffic. Snow storage space is also required in the square.

3. No big snowdrifts are to be permitted on the pedestrian network among the public transportation points in winter. People want to transfer between the JR line and a public bus or taxi without the barrier of snowdrifts. 


\subsection{Comparing the covered walk design for preventing from the snow}

The JR Wakkanai railway station, a public bus station, a taxi bay and the requirements of private vehicular traffic should be integrated with the station square to allow for smooth transfer among them. At present they are separate and transfer is inconvenient. Consideration given to pedestrian access among these transportations will be required in the redevelopment plan.

Author focused on snow impacts of distinguish of the CW site plan between Leeward side and Windward side type. The both general site plan showed on Fig. 8. and Fig.9. The idea of Leeward side CW type was protecting pedestrian's activities on the station square and pedestrian's activities on the pedestrian way from snow and strong wind. Windward side CW type also had a concept protecting pedestrian's activities from snow and strong wind. Both CW type had sidewalls partially around one-third of the total length.

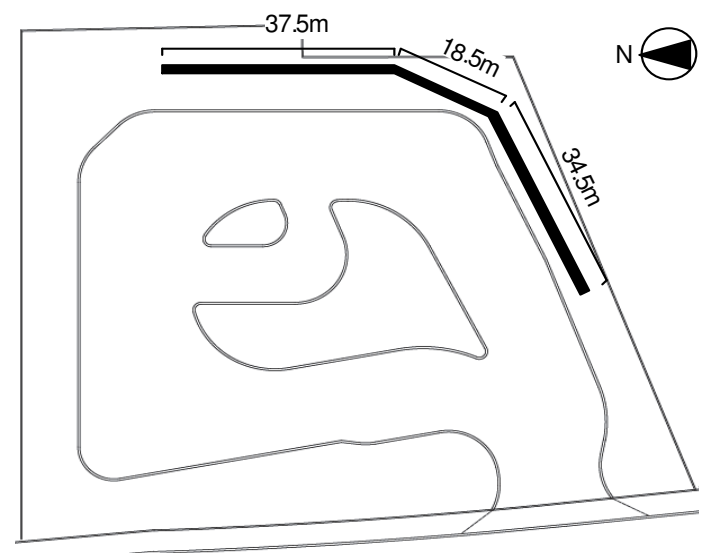

Fig. 8. Site plan of Leeward side CW type

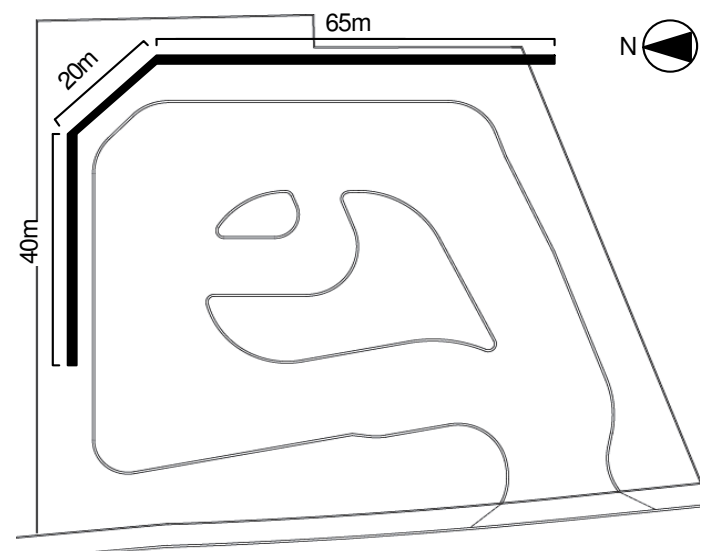

Fig. 9. Site plan of Windward side CW type 


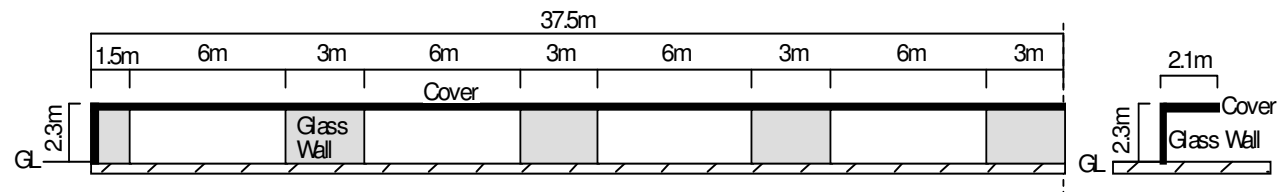

Fig. 10. Section of the Covered-Walk (part) (gray parts are glass walls)

Fig. 10 shows the section plan of the both CW type. The height of the CW should be as low as possible because of preventing from the snow storm. The length of the roof $2.1 \mathrm{~m}$ is similar to the height for the same reason. The $\mathrm{CW}$ has $3 \mathrm{~m}$ glass walls every $9 \mathrm{~m}$ pitch, the walls may prevent pedestrian from snow storm. All of the side of $\mathrm{CW}$ covered the glass walls is not good design because it will cause the snowdrift inside the CW.

\section{Results of the snow simulation experiments}

In the findings of the snow simulation tests with snow and wind, several snow problems were observed with both of the CW designs for the new Wakkanai Station Square planning.

\subsection{Leeward side CW type (fig. 11)}

1. A big snowdrift was formed around the leeward side CW comparing to Windward side type (see point A). The snowdrifts in the station square were caused by the backlash of snow and wind from the Station Complex Center. The backlash of snow and wind flooded the $\mathrm{CW}$, reducing its wind velocity, thereby causing the snowdrifts there. Snowdrifts at the bus stops negatively impact passengers.

2. A big snowdrift was formed on the windward side of the station square even though no CW is located there (see point B). It was assumed to be caused by the reduced velocity of the wind as it streamed from the narrow street to the wide station square. If a snowdrift forms along the $\mathrm{CW}$ in the square, it will negatively impact the vehicles there.

\subsection{Windward CW type (fig. 12)}

1. On the windward CW type, a big snowdrift was not formed around the bus stops comparing to Leeward side type (see point C). There was no barrier backlash of snow and wind from the Station Complex Center, as wind streamed through to the center of the square. No passengers or vehicles will be inconvenienced by snowdrifts in this situation. But grass shelters will be required at the bus stops for protecting the passengers from the strong and cold winds.

2. The snowdrift on the windward side of the square was big, but it formed smaller than the Leeward side CW type (see point D). Author figured out the reason that the CW prevented wind and snow from north and northeast direction for making snowdrift on the windward side of the station square. The spread of the snowdrift would have less impact on vehicular traffic in the square. Bus stops and taxi bays should be planned to exclude this area. 
$\leftarrow \leftarrow$ Windward side (North)

Leeward side (South) $\rightarrow \rightarrow \rightarrow$

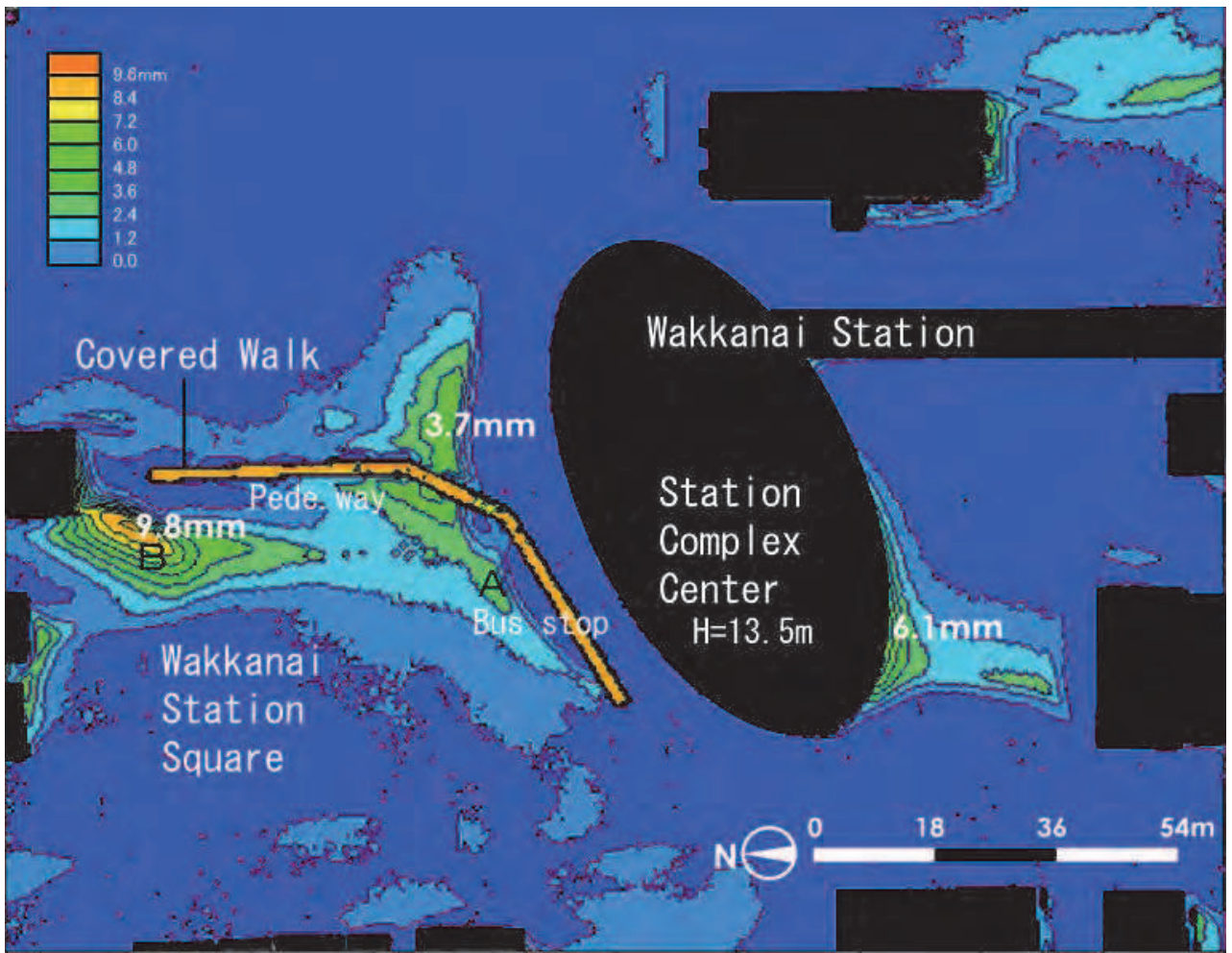

(Numeric values mean the height of powder draft of the model)

Fig. 11. Snow and wind simulation test of Leeward side Covered Walk (CW) type

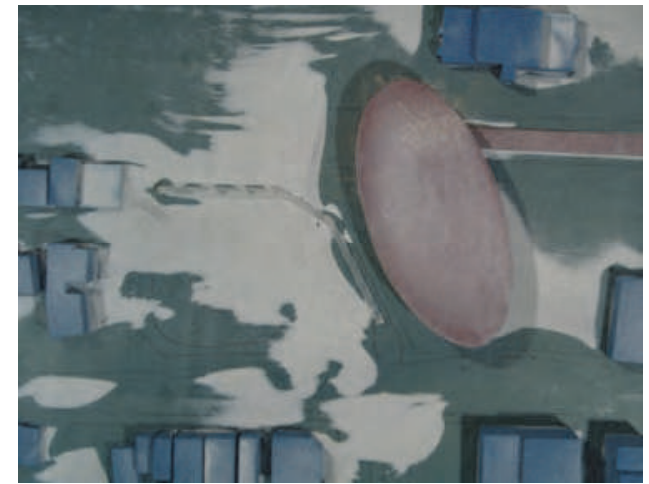

from above (left)

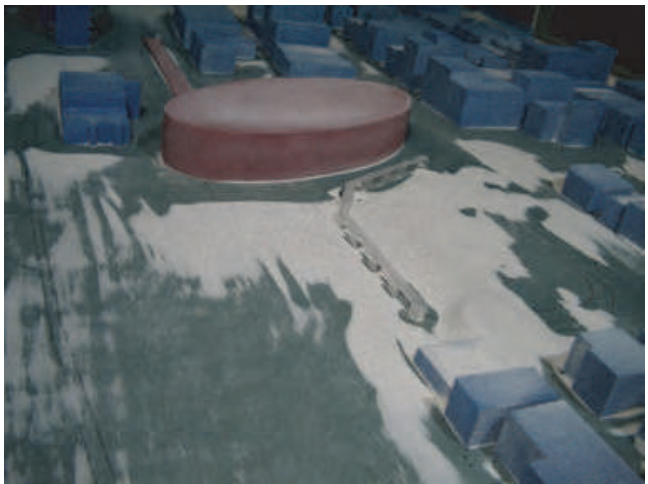

from windward side (right)

Photo 3. Snow simulation result of Leeward side Covered Walk type 
$\leftarrow \leftarrow$ Windward side (North)

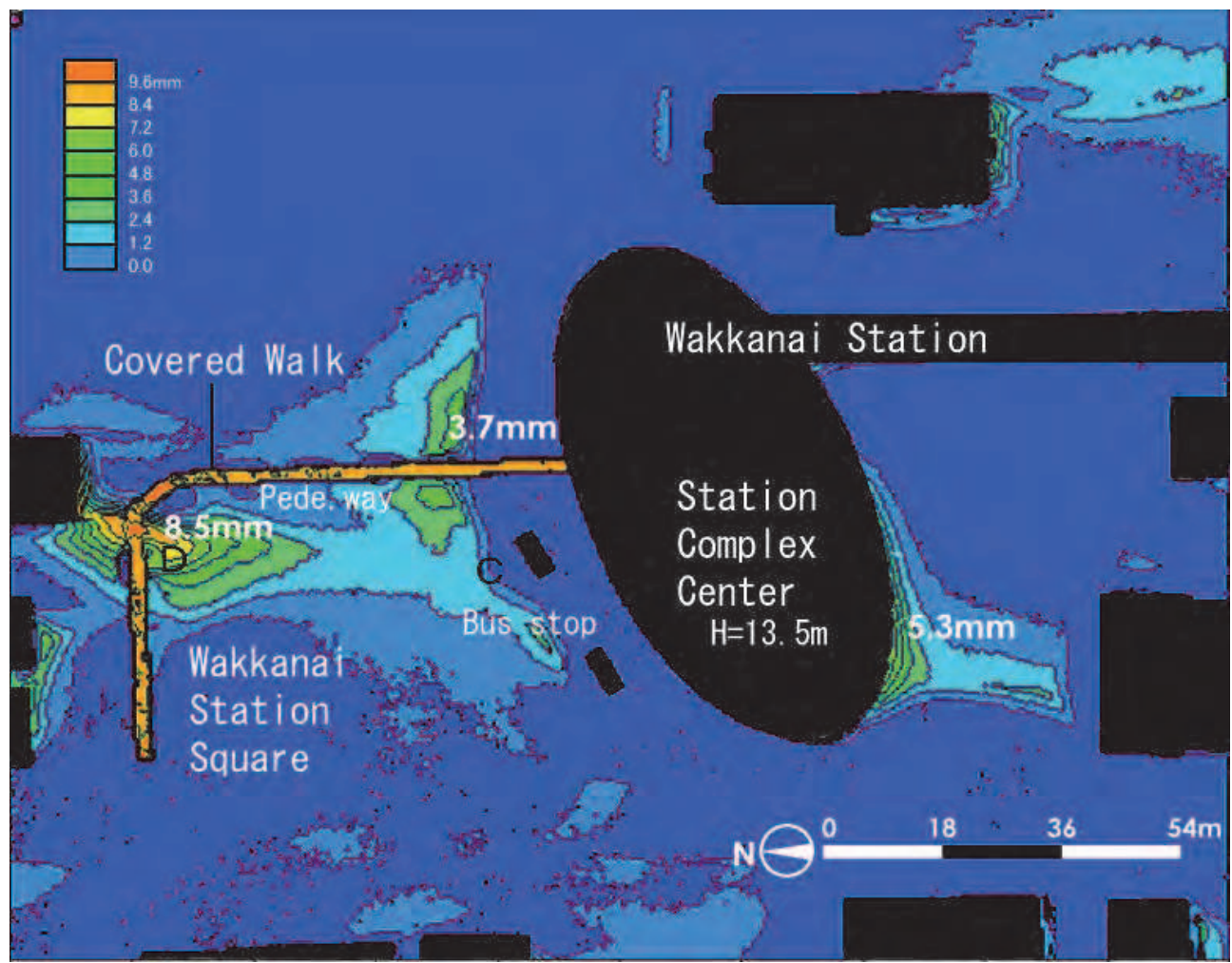

(Numeric values mean the height of powder draft of the model)

Fig. 12. Snow and wind simulation test of Windward side Covered Walk (CW) type

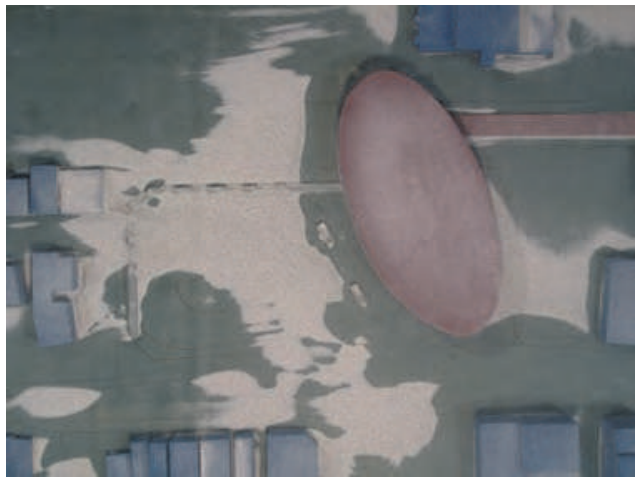

from above (left)

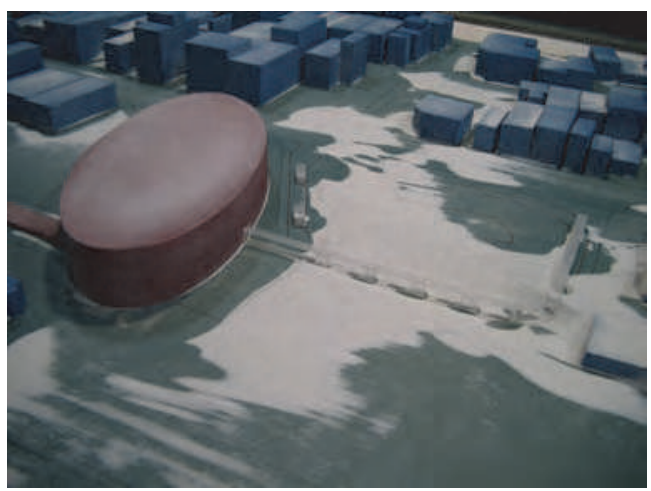

from windward side (right)

Photo 4. Snow simulation result of Windward side Covered Walk type 


\section{Conclusions}

In the findings of the snow simulation tests with snow and wind, several snow problems were observed with both of the CW designs for the Wakkanai Station Square renewal planning. On the leeward side CW type simulation, a big snowdrift was formed around the leeward side of CW (Fig. 11). On the other side, on the windward CW type, a big snowdrift was not formed around the bus stops (Fig. 12). Comparing the two types of CW design, the Windward side CW type is better suited to alleviate the impact of heavy snowfall in the new Wakkanai Station Square development because the formation of snowdrifts are less likely to occur to the passenger area that riding on the buses and pedestrian areas walking along the $\mathrm{CW}$. The finding that a big snow barrier like the CW caused snowdrifts to form around it and snow inconveniences to pedestrian and bus transit during the winter season in Wakkanai was very interesting. It is assumed that the $\mathrm{CW}$ reduced wind speed and contributed to form the snowdrift along the CW. The $\mathrm{CW}$ has not to be located at right angle to the main wind direction in winter. The CW has to be designed carefully to its site plan and section plan.

It is very important to make the snow and wind simulations using wind tunnel on the process of the public square design project in these snowy and cold regions. The problems caused by snow and wind are pointed out clearly and those problems should be reflected to the public space design and urban design. The results of this simulation also should be reflected in the square planning and design of this project.

These snow simulations were tested only two site design type of $\mathrm{CW}$, then more variable $\mathrm{CW}$ design e.g. wall design and height have to be tested on the snow simulations. Father more, the snow simulation on real atmospheric phenomena should be required because this was verifiable only through the conduction of snow simulation tests incorporating a wind tunnel.

\section{Sustainable design approach relationship between urban design and environmental planning}

On the Wakkanai Station Square design studies with snow simulations author realized the new sustainable design approaches relationship between Urban Design and Environmental Planning. Especially in these cold and snowy cities, this sustainable design approaches should be required on these urban design projects. Author developed the new urban design approach with snow simulations using wind tunnel as follow steps (Table 3).

\section{Notes}

1. The Designing CW is one of the most important items for pedestrian network on this project.

2. Heavy Snow Area: The local government that has $5,000 \mathrm{~cm}$ by days and more snowfall in total in last 30 years. Multiplying the height of snow stock per day by snow stock days gives the $\mathrm{cm}^{*}$ days.

Particular Heavy Snow Area: The local government that has $15,000 \mathrm{~cm}^{*}$ days and more snowfall in total in last 20 years.

3. Manufactured by Keyence LK2500

4. The white soil powder has $8.5 \%$ of moisture content and the average of diameter has $20 \mu \mathrm{m}$. It means very dry and small particle powder.

5. The station square is planed four bus bays, three taxi bays and four bays for private vehicles on the Wakkanai Station Square project. 


\begin{tabular}{|c|c|}
\hline Urban Design Approaches & Environmental Planning Approaches \\
\hline \multicolumn{2}{|l|}{$\begin{array}{l}\text { 1) Urban design approach \#1 } \\
\text { - Making planning criteria contribute to the } \\
\text { downtown revitalization. } \\
\text { - Several alternative designing plans are } \\
\text { proposed depend on these planning } \\
\text { criteria. }\end{array}$} \\
\hline \multirow[t]{2}{*}{$\begin{array}{l}\text { Urban Design Approaches } \\
\text { (continue) }\end{array}$} & $\begin{array}{l}\text { Environmental Planning Approaches } \\
\text { (continue) }\end{array}$ \\
\hline & $\begin{array}{l}\text { 2) Environmental planning approach \#1 } \\
\text { - The experiments of the snow simulations } \\
\text { using wind tunnel for the alternative } \\
\text { design plans. } \\
\text { - Environmental evaluations to the results } \\
\text { of the snow simulations on the alternative } \\
\text { design plans. }\end{array}$ \\
\hline \multirow[t]{2}{*}{$\begin{array}{l}\text { 3) Urban design approach } \# 2 \\
\text { - Development to the design guidelines } \\
\text { depend on the results of the snow } \\
\text { simulations. Each alternative design plan } \\
\text { has good and considerable points in the } \\
\text { results of the simulations. For promoting } \\
\text { more useful to the results of the snow } \\
\text { simulations, the design guidelines are able } \\
\text { to reflect those ideas of the simulations. }\end{array}$} & \\
\hline & $\begin{array}{l}\text { 4) Environmental planning approach } \# 2 \\
\text { - More response to the environmental } \\
\text { conditions of snow problems, snow } \\
\text { drifting and strong wind on the detail } \\
\text { planning of the projects. }\end{array}$ \\
\hline $\begin{array}{l}\text { 5) Urban design approach \#3 } \\
\text { - On the designing process of the station } \\
\text { square more detail designing points reflect } \\
\text { from the design guidelines. }\end{array}$ & \\
\hline
\end{tabular}

Table 3. Sustainable design approach relationship between Urban Design and Environmental Planning

\section{References}

[1] Bosselmann, P. (1984). Sun, wind, and comfort - A Study of Open Spaces and Sidewalks in Four Downtown Area -. Environmental Simulation Laboratory University of California Berkeley, USA,

[2] Bosselmann, P. and Arens, E. (1989). Wind, sun and temperature - predicting the thermal comfort of people in outdoor spaces. Building and Environment, Vol.24, No.4, pp315-320, USA 
[3] Bosselmann, P. (1998). Representation of Places - Reality and Realism in City Design -, Downtown Toronto Urban Form and Climate, University of California Press, USA

[4] Pressman, N. and Zepic, X. (1986), Planning in cold climates. Institute of Urban Studies, Canada

[5] Pressman, N. (1995), Northern cityscape - linking design to climate -. Winter Cities Association, Canada

[6] Setoguchi, T. (2003). A Study on Efficiencies for Reducing Snow Damages on Infill Developments in Downtown Area, The proceedings of International Symposium on City Planning, 2003.9, Japan

[7] Setoguchi, T. (2004), Efficiencies of Infill Developments against Snow Problem in Winter Cities - The Snow Simulations for Desirable Block Designs Using Wind Tunnel -, Journal of Asian Architecture and Building Engineering, 2004.11, pp335-340

[8] Tomabechi, T. (2002). Influence of snow around the building on evacuation activities, Journal of Architecture, Planning and Environmental Engineering, No.560, 2002.10, pp167-172, Japan

[9] Yoshizaka, T. (1942). The Model Study on the Snow Stock Environments Surrounding of Buildings, Snow and Ice, Japan 


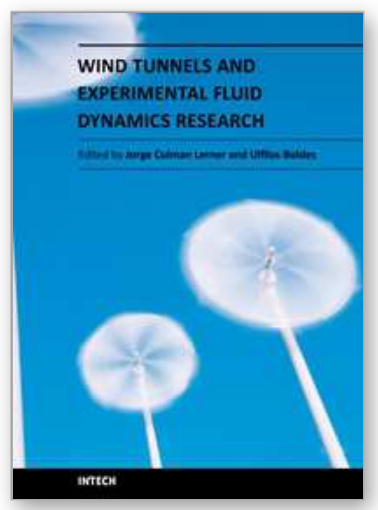

\author{
Wind Tunnels and Experimental Fluid Dynamics Research \\ Edited by Prof. Jorge Colman Lerner
}

ISBN 978-953-307-623-2

Hard cover, 709 pages

Publisher InTech

Published online 27, July, 2011

Published in print edition July, 2011

The book â€œWind Tunnels and Experimental Fluid Dynamics Researchâ€ is comprised of 33 chapters divided in five sections. The first 12 chapters discuss wind tunnel facilities and experiments in incompressible flow, while the next seven chapters deal with building dynamics, flow control and fluid mechanics. Third section of the book is dedicated to chapters discussing aerodynamic field measurements and real full scale analysis (chapters 20-22). Chapters in the last two sections deal with turbulent structure analysis (chapters 23-25) and wind tunnels in compressible flow (chapters 26-33). Contributions from a large number of international experts make this publication a highly valuable resource in wind tunnels and fluid dynamics field of research.

\title{
How to reference
}

In order to correctly reference this scholarly work, feel free to copy and paste the following:

Tsuyoshi Setoguchi (2011). Public Square Design with Snow and Wind Simulations Using Wind Tunnel, Wind Tunnels and Experimental Fluid Dynamics Research, Prof. Jorge Colman Lerner (Ed.), ISBN: 978-953-307623-2, InTech, Available from: http://www.intechopen.com/books/wind-tunnels-and-experimental-fluiddynamics-research/public-square-design-with-snow-and-wind-simulations-using-wind-tunnel

\section{INTECH}

open science | open minds

\section{InTech Europe}

University Campus STeP Ri

Slavka Krautzeka 83/A

51000 Rijeka, Croatia

Phone: +385 (51) 770447

Fax: +385 (51) 686166

www.intechopen.com

\section{InTech China}

Unit 405, Office Block, Hotel Equatorial Shanghai

No.65, Yan An Road (West), Shanghai, 200040, China

中国上海市延安西路65号上海国际贵都大饭店办公楼 405 单元

Phone: +86-21-62489820

Fax: $+86-21-62489821$ 
(C) 2011 The Author(s). Licensee IntechOpen. This chapter is distributed under the terms of the Creative Commons Attribution-NonCommercialShareAlike-3.0 License, which permits use, distribution and reproduction for non-commercial purposes, provided the original is properly cited and derivative works building on this content are distributed under the same license. 